\title{
THE GROSS DIRECT PREMIUM INCOME UNDER GENERAL AND HEALTH INSURANCE: A SEGMENT - WISE ANALYSIS OF INDIAN PUBLIC SECTOR INSURERS
}

\author{
Tulilekha Sil ${ }^{1} \&$ Akash Balmiki ${ }^{2}$ \\ ${ }^{1}$ State-Aided College Teacher, Department Of Commerce, Sonarpur Mahavidyalaya, Kolkata, India \\ ${ }^{2}$ Assistant Professor, Department Of Commerce, Vivekananda College, Thakurpukur, Kolkata, India
}

Article DOI: https://doi.org/10.36713/epra9189

DOI No: 10.36713/epra9189

\begin{abstract}
Insurance business is broadly classified under the two heads - Life Insurance and General Insurance. Life Insurance Corporation of India (LICI) and General Insurance Corporation of India (GICI) are the key players in the public sector. The Indian insurance market consists of many private players as well. The gross direct premium has been the income sources for the insurance business. This study shall highlight the gross direct premium income specifically under the General and Health insurance business of the Indian public sector insurers.
\end{abstract}

\section{BACKGROUND OF THE STUDY}

Insurance policy is a contract between the insured and the insurance company to reimburse losses, dispense financial assistance and secure the health, life and other materialistic products. Safety and security has been a concerning issue over the years, the pandemic has highlighted the importance of insurance. General insurance is equally important, general insurance often termed as non - life insurance, secures from financial losses with products like fire insurance, marine insurance, motor insurance, health insurance and other insurance business.

In India, Insurance Regulatory and Development Authority of India (IRDAI) is the apex institution monitoring and regulating the insurance industry. As per the report of India Brand Equity Foundation (IBEF), the market size of Indian insurance market is nearly US\$280 billion as reported in 2020. The Indian insurance sector consists of 57 insurance companies. The non - life insurance business consists of six companies in public sector, the General Insurance Corporation of India (GICI) is the sole national re-insurer. IBEF reports, an increase in the market share of the private sector companies from $47.97 \%$ in FY19 to $48.03 \%$ in FY20 for the general and health insurance sector.
The gross direct premium income of non - life insurance companies recorded a growth of $11.4 \%$ (May, 2021) on yearly basis and the non - life insurance sector expects a growth of $7 \%$ to $9 \%$ with reference to gross direct premium income in FY22. IBEF also reports that the demographic factors like middle class income group, young insurable population and awareness programmes for the need of protection and retirement planning may be contributing factors for the growth in Indian insurance market.

The prospect of the Indian insurance sector is very evident. The non - life insurance sector has recorded a growth in gross direct premium income over the years. The researchers have made an attempt to study the segment - wise growth of the non - life insurance under the four public sector companies National Insurance Co. Ltd, The New India Assurance Co. Ltd, The Oriental Insurance Co. Ltd and United India Insurance Co. Ltd. for the past decade i.e. $2010-11$ to $2019-20$.

\section{OBJECTIVES OF THE STUDY}

The study concentrates on the Gross Direct Premium Income (GDPI) of four leading public sector insurers under non-life insurance segment and aims at the following objectives: 
- To provide an overview on the GDPI generated by the four public sector companies for the period $2010-11$ to 2019 -20 ;

- To statistically analyse the major segment based GDPI earned for the period $2010-11$ to $2019-20$.

\section{ANALYSIS}

Gross Direct Premium Income (GDPI) has experienced a constant strong increase over the years for all the leading four public sector insurance companies operating in India. For National Insurance Co. Ltd, premium income has increased from Rs. 6220.70 crores in F.Y. 2010-11 to Rs. 15262.22 crores in F.Y. 2019-20, maintaining an average growth rate of $10.87 \%$ over last 10 years. For The New India Assurance Co. Ltd, premium income has increased to Rs. 26813.13 crores in F.Y. 2019-20 from Rs. 7097.14 crores in F.Y. 2010-11, maintaining an average growth rate of $16.04 \%$ over last 10 years. For The Oriental Insurance Co. Ltd, premium income has increased to Rs. 13672.65 crores in F.Y. 2019-20 from Rs. 5457.33 crores in F.Y. 2010-11, with an average growth rate of $11 \%$ over last 10 years. For United India Insurance Co. Ltd, premium income has increased from Rs. 6376.67 crores in F.Y 2010-11 to Rs. 17515.09 crores in F.Y 2019-20, keeping an average growth rate of $12.40 \%$ over last 10 years.

These four leading public sector insurers (previously the subsidiaries of GICI till $21^{\text {st }}$ March, 2003) are engaged in different segments namely, fire insurance, marine insurance, motor insurance, health insurance and other insurance businesses.

Table 01: Percentage showing average contribution of each segment in generating Gross Direct Premium Income of Insurance Business

\begin{tabular}{|c|c|c|c|c|c|}
\hline \multicolumn{2}{|c|}{ COMPANIES } & \multicolumn{3}{|c|}{ DIFFERENT SEGMENTS OF INSURANCE BUSINESS } \\
\cline { 2 - 6 } & Fire & Marine & Motor & Health & Others \\
\hline National Insurance Co. Ltd (NI) & $7.59 \%$ & $2.72 \%$ & $44.48 \%$ & $32.95 \%$ & $12.26 \%$ \\
\hline The New India Assurance Co. Ltd (NIA) & $11.68 \%$ & $4.84 \%$ & $37.72 \%$ & $31.71 \%$ & $14.05 \%$ \\
\hline The Oriental Insurance Co. Ltd (OI) & $11.18 \%$ & $5.14 \%$ & $35.56 \%$ & $31.19 \%$ & $16.93 \%$ \\
\hline United India Insurance Co. Ltd (UI) & $10.32 \%$ & $4.44 \%$ & $37.86 \%$ & $31.65 \%$ & $15.73 \%$ \\
\hline
\end{tabular}

Table 01 represents the average contribution of each segment in generating gross direct premium income for all the four companies over last 10 years. Among all the major segments, it was observed that in all the four companies, Motor insurance business has contributed the highest in generating direct premium income over last years followed by health insurance, fire insurance, marine insurance and others. 

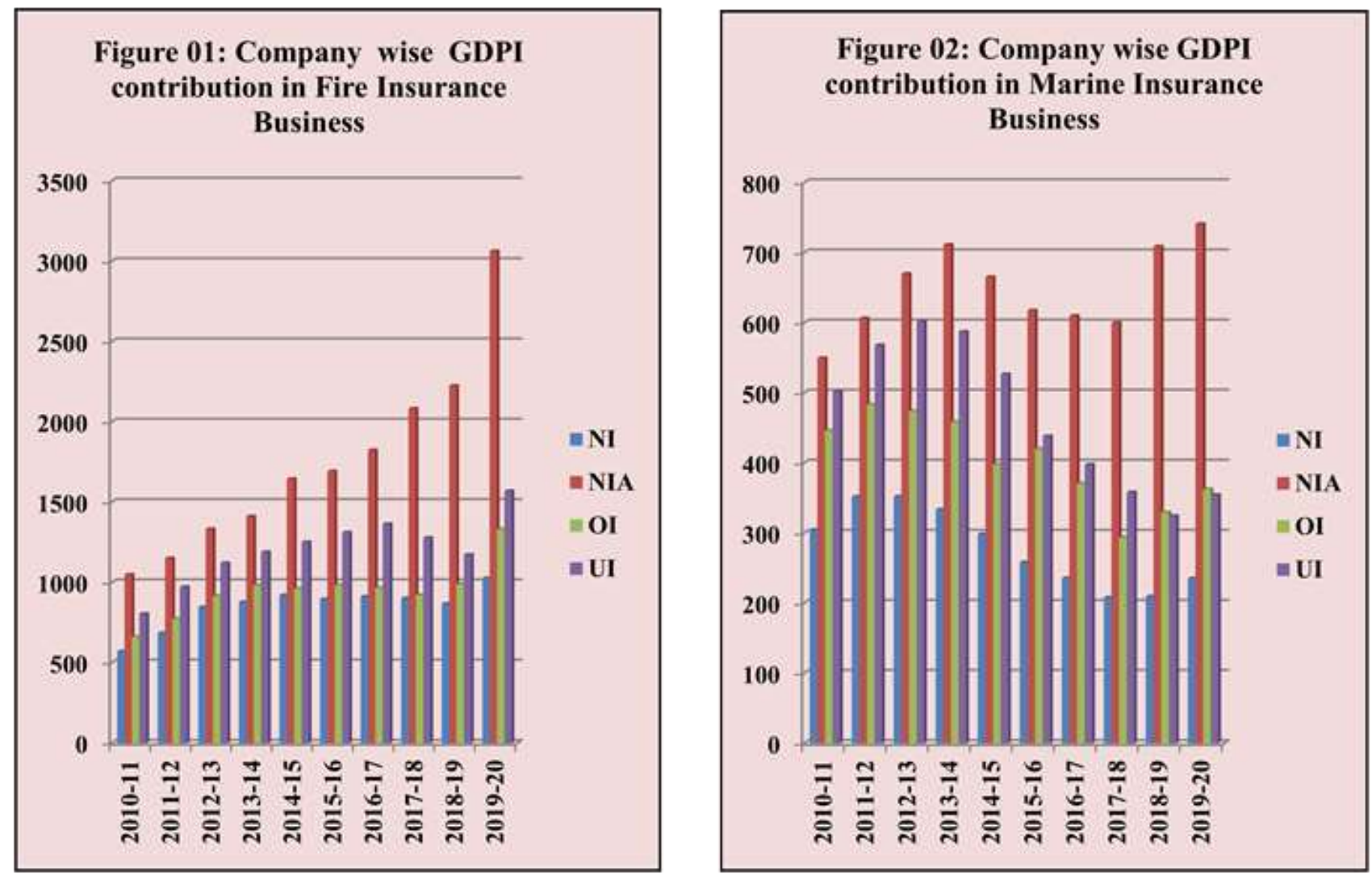

Source: Compiled by Researchers (Through MS-Excel)
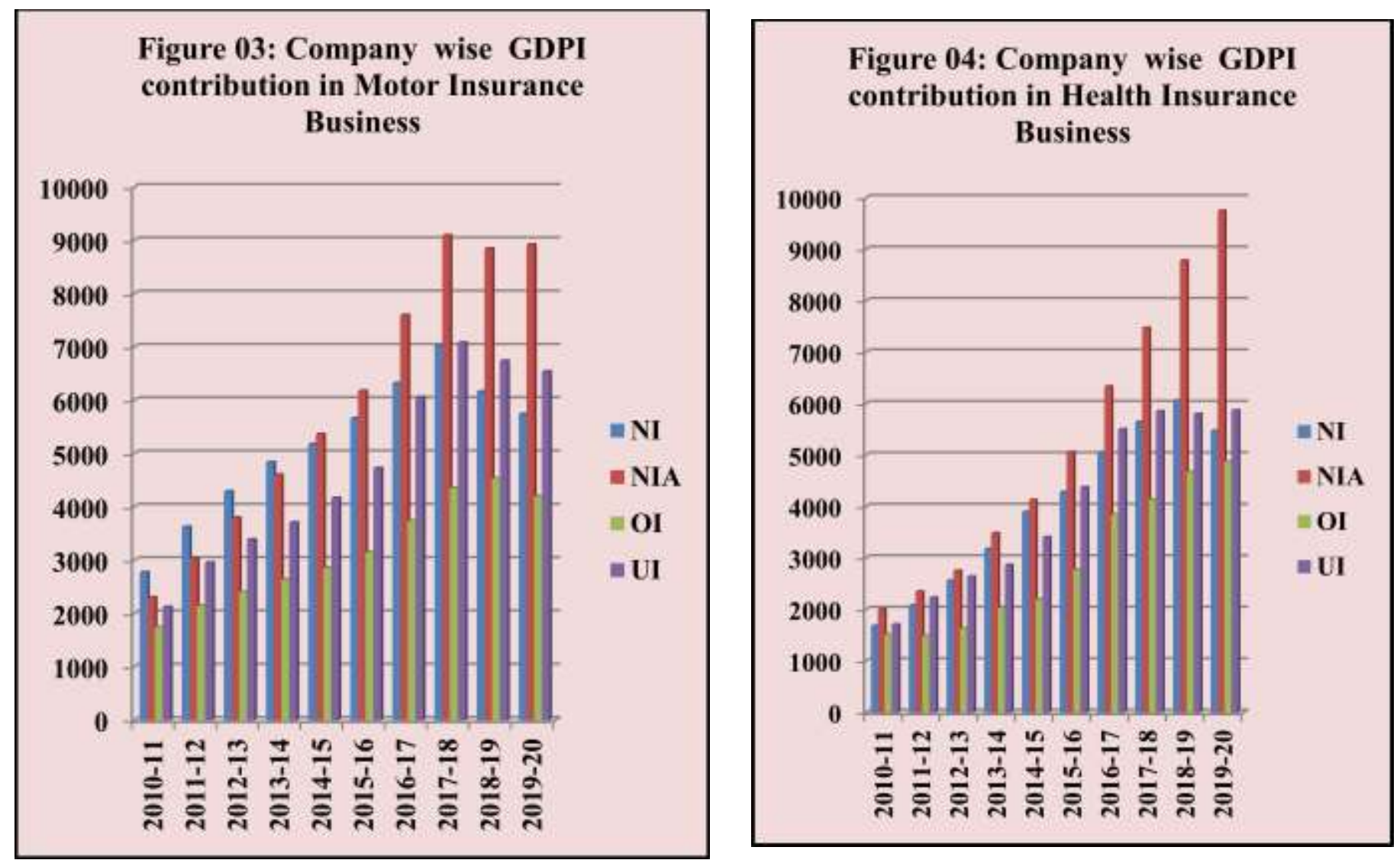


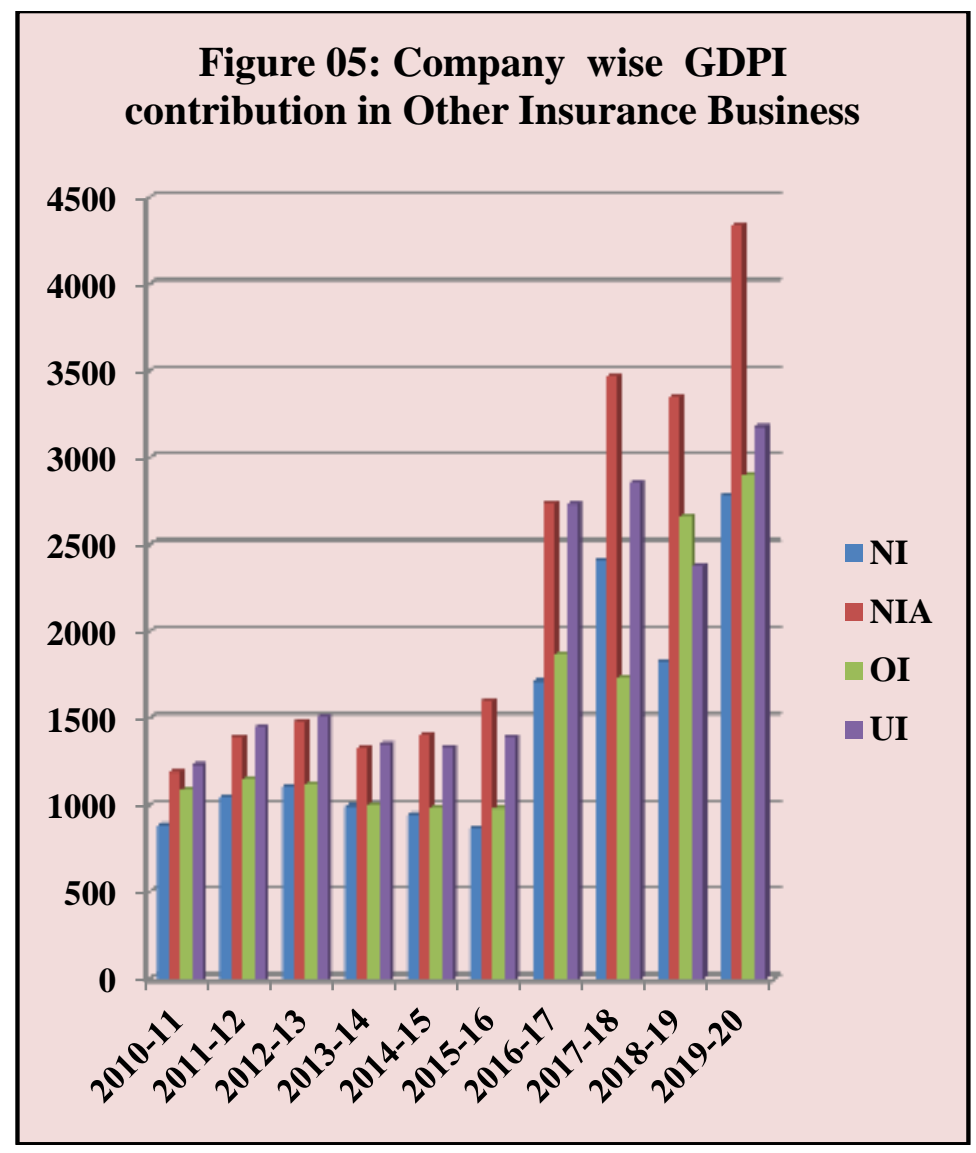

Source: Compiled by Researchers (Through MS-Excel)

Considering the segment-wise analysis of different insurance businesses as managed by these public sector companies, the following facts have been observed:

$>$ In Fire Insurance Business, The New India Assurance Co. Ltd has shown a persistent increase in premium income earned over the years, being the highest among all the four companies followed by United India Insurance Co. Ltd, being the second highest in income generation. The Oriental Insurance Co. Ltd is at the third level whereas National Insurance Co. Ltd is the least performer among all the companies (Figure 01).

$>$ In Marine Insurance Business too, the trend in performance of all the four companies remained same as that of fire insurance business i.e. The New India Assurance Co. Ltd being the best contributor in generating direct premium income followed by United India Insurance Co. Ltd, The Oriental Insurance Co. Ltd and National Insurance Co. Ltd respectively (Figure 02).

$>$ In Motor Insurance Business, for the first four years considered in the study i.e. from 2010-11 to 2013-14, National Insurance Co. contributed highest in direct premium earnings whereas from 2014-15 onwards, the position was taken over by The New India Assurance co. which experienced a strong and consistent increase in premium earnings. It was followed by United India insurance co. and The Oriental Insurance co. respectively (Figure 03).

$>$ In Health Insurance Business, till 2014-15, both The New India Assurance and National Insurance contributed hand-in-hand in premium earnings, but 2015-16 onwards, The New India assurance surpassed National Insurance in income generation. United India Insurance and The Oriental Insurance continued to remain in the third and fourth position respectively over the years considered (Figure 04).

$>$ Considering all insurance business other than the four specifically mentioned above, The New India Assurance Co. still secured the best position in generating premium income followed by United India Insurance, The Oriental India insurance and National India insurance respectively (Figure 05).

Accordingly, to check whether there exists any variation in gross direct premium income generated by the four companies through various insurance businesses considered over the years, a statistical test 
of Analysis of Variance (ANOVA) has been performed through one-way analysis. As ANOVA is a parametric test, the researchers have checked the normality of the data through SPSS considering $5 \%$ level of significance.

\section{Hypothesis Formulation}

H01: There exists no significant difference in Total Gross Direct Premium Income generated by the four companies through various insurance businesses over last 10 years.

\begin{tabular}{|c|c|c|c|c|c|c|}
\hline \multicolumn{7}{|c|}{ Table 02 : Results of ANOVA for Gross Direct Premium Income (in crores) among the companies } \\
\hline Basis & $\begin{array}{c}\text { Sources of } \\
\text { Variation }\end{array}$ & Sum of Squares & $\begin{array}{c}\text { Degrees of } \\
\text { Freedom }\end{array}$ & Mean Square & F-Statistic & Sig. \\
\hline $\begin{array}{c}\text { Gross Direct } \\
\text { Premium } \\
\text { Income (In } \\
\text { Crores) }\end{array}$ & $\begin{array}{c}\text { Between } \\
\text { companies }\end{array}$ & 235121182.342 & 3 & 78373727.447 & 3.637 & 0.022 \\
\cline { 2 - 7 } & $\begin{array}{c}\text { Within } \\
\text { companies }\end{array}$ & 775701544.235 & 36 & 21547265.118 & & \\
\cline { 2 - 7 } & Total & 1010822726.576 & 39 & & \\
\hline \multicolumn{7}{|c|}{ Source: Compiled by Researchers (Through SPSS) } \\
\hline
\end{tabular}

From Table 02, the value of F-Statistic for Gross Direct Premium income is 3.637 with a significance value (0.022) less than 0.05 , indicating a significant difference between gross direct premium income generated by the four companies through various insurance businesses in last 10 years, leading to the rejection of null hypothesis at $5 \%$ level of significance and acceptance of alternative hypothesis.
Simultaneously, to classify the first research hypothesis as well as to statistically justify the analysis as in Table 01, a segment - wise analysis of variance has been performed through Friedman's Test where mean ranks have been assigned to individual segment based on their contribution in premium earnings over the period considered in the study.

\section{Hypothesis Formulation}

H02: There exists no significant difference in the mean ranks provided to the different segments based on their contribution in generating gross direct premium income of four companies over last 10 years.

\begin{tabular}{|c|c|c|c|c|c|c|}
\hline \multicolumn{7}{|c|}{ Table 03 : Segment-wise analysis of variance by ranks - Friedman's Test } \\
\hline Companies & Segments & $\begin{array}{l}\text { Mean } \\
\text { Rank }\end{array}$ & $\begin{array}{c}\text { Chi-Square } \\
\text { value }\end{array}$ & $\begin{array}{c}\text { Degrees of } \\
\text { Freedom }\end{array}$ & Sig. & Decision \\
\hline \multirow{5}{*}{$\begin{array}{c}\text { National Insurance Co. } \\
\text { Ltd }\end{array}$} & Motor & 5.00 & \multirow[t]{5}{*}{39.280} & \multirow[t]{5}{*}{4} & \multirow[t]{5}{*}{0.000} & \multirow{5}{*}{$\begin{array}{l}\text { Reject the } \\
\text { Null } \\
\text { Hypothesis }\end{array}$} \\
\hline & Health & 4.00 & & & & \\
\hline & Others & 2.90 & & & & \\
\hline & Fire & 2.10 & & & & \\
\hline & Marine & 1.00 & & & & \\
\hline \multirow{5}{*}{$\begin{array}{c}\text { The New India } \\
\text { Assurance Co. Ltd }\end{array}$} & Motor & 4.90 & \multirow[t]{5}{*}{37.600} & \multirow[t]{5}{*}{4} & \multirow[t]{5}{*}{0.000} & \multirow{5}{*}{$\begin{array}{l}\text { Reject the } \\
\text { Null } \\
\text { Hypothesis }\end{array}$} \\
\hline & Health & 4.10 & & & & \\
\hline & Others & 2.70 & & & & \\
\hline & Fire & 2.30 & & & & \\
\hline & Marine & 1.00 & & & & \\
\hline \multirow{5}{*}{$\begin{array}{c}\text { The Oriental Insurance } \\
\text { Co. Ltd }\end{array}$} & Motor & 4.70 & \multirow[t]{5}{*}{37.600} & \multirow[t]{5}{*}{4} & \multirow[t]{5}{*}{0.000} & \multirow{5}{*}{$\begin{array}{l}\text { Reject the } \\
\text { Null } \\
\text { Hypothesis }\end{array}$} \\
\hline & Health & 4.30 & & & & \\
\hline & Others & 2.90 & & & & \\
\hline & Fire & 2.10 & & & & \\
\hline & Marine & 1.00 & & & & \\
\hline \multirow{5}{*}{$\begin{array}{l}\text { United India Insurance } \\
\text { Co. Ltd }\end{array}$} & Motor & 5.00 & \multirow[t]{5}{*}{40.000} & \multirow[t]{5}{*}{4} & \multirow[t]{5}{*}{0.000} & \multirow{5}{*}{$\begin{array}{l}\text { Reject the } \\
\text { Null } \\
\text { Hypothesis }\end{array}$} \\
\hline & Health & 4.00 & & & & \\
\hline & Others & 3.00 & & & & \\
\hline & Fire & 2.00 & & & & \\
\hline & Marine & 1.00 & & & & \\
\hline & Source & 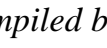 & & PSS) & & \\
\hline
\end{tabular}


Table 03 shows that the significance value in all the four companies is less than 0.05 , leading to rejection of null hypothesis at $5 \%$ level of significance in all the cases concluding that there exists a significant difference in gross direct premium income generated by all the five segments for all the companies. Based on the mean ranks, it has been observed that for all the four companies, motor business has contributed the highest in generating premium income followed by health, others, fire and marine businesses.

\section{CONCLUSION}

The Indian public sector insurance companies had witnessed an average growth of at least $10 \%$ in premium income over the last decade. Considering the average contribution of each segment, it has been observed that motor insurance segment dominates other insurance segments for all the four public sector companies and the prime reason is the compulsion of motor insurance imposed by the government. According to Figure 01, 02, 03 and 04, The New India Assurance Co. Ltd. has witnessed the highest contribution across all the five segments in the year 2019 - 20. The ANOVA results (Table 02), concludes that the Gross Direct Premium Income (GDPI) of four public sector companies in the last decade is significantly different. Further, Friedman's Test results also conclude that there exists a significant difference in GDPI generated by the five segments for the four public sector companies. Motor insurance segment generates highest GDPI. The general and health insurance business has shown a good growth rate in the last decade and the non - life insurance business also reflects a promising growth in future.

\section{REFERENCES}

1. Handbook on Indian Insurance Statistics (2013 14) issued by Insurance Regulatory and Development Authority of India (IRDAI).

2. Handbook on Indian Insurance Statistics (2019 20) issued by Insurance Regulatory and Development Authority of India (IRDAI)

3. https://www.ibef.org/industry/insurance-sectorindia.aspx

4. https://financialservices.gov.in/insurancedivisions/Public-Sector-Insurance-Companies 